\title{
Relationships between Hearing Symptoms, Attitudes toward Noise, and Use of Hearing Protection among College Students
}

\author{
Min Kyung Han, , SeonJin Kim ${ }^{\mathrm{b}}$ \\ ${ }^{a}$ Department of Communication Disorders, Indiana State University, Indiana, USA \\ ${ }^{b}$ Department of Statistics, Miami University, Ohio, USA
}

Correspondence: Min Kyung Han, PhD Communication Disorders, Indiana State University, 401 north 7th St., Terre Haute, Indiana 47809 , USA

Tel: $+1-812-237-3780$

Fax: +1-812-237-2729

E-mail: min.han@indstate.edu

Received: April 3, 2021

Revised: May 21, 2021

Accepted: May 21, 2021

This research was supported by the Indiana Lions Speech and Hearing Project: McKinney Outreach Research Support awarded to Han.

\begin{abstract}
Objectives: This study aimed to examine the relationships between college students' hearing symptoms, attitudes toward noise, and use of hearing protection in two situations: exposure to high levels of sound in noisy environments and unsafe use of personal listening devices (PLDs). Methods: A total of 278 college students completed an anonymous online survey regarding their experience with hearing symptoms associated with their exposure to noise, attitudes toward noise, and use of hearing protection. Results: Over $84 \%$ of the college students reported experiencing at least one hearing symptom with limited concentration at the highest rate of experience. When the college students were exposed to noise, there were significant associations between college students' hearing symptoms, attitudes toward noise, and use of hearing protection in the two situations. However, when using personal listening devices, there was insignificant association between hearing symptoms and attitudes toward noise; and use of hearing protection was associated with hearing symptoms but not with attitudes toward noise. Conclusion: College students' experience with and perception of noise may influence their behavior in preventing hearing loss. It may be beneficial if hearing conservative programs emphasize educating college students of the negative effects of noise and changing their attitudes toward noise, which can help them take preventative measures against noise-induced hearing loss.
\end{abstract}

Keywords: Noise-induced hearing loss (NIHL), Hearing symptoms, Youth attitudes to noise, Hearing protection
The World Health Organization (2015) reported that 1.1 billion teenagers and young adults worldwide are at risk for developing hearing loss due to exposure to high levels of sound in noisy entertainment places and unsafe listening practices with personal listening devices (PLDs). College students are involved in various non-occupational voluntary activities in noisy environments such as nightclubs, concerts, and sporting events (e.g., Berger, Neitzel, \& Kladden, 2015). Moreover, during the past few decades, college students' use of PLDs has increased explosively with the release of MP3 devices and the popularity of new media platforms (e.g., Kreisman, Longenbach, Blasi, Fligor, \& John, 2019). Many studies have investigated potential damage to hearing that may be attributed to college students' involvement in activities in noisy environments (e.g., Balanay \& Kearney, 2015; Widén, Holmes, \& Erlandsson, 2006) and use of PLDs (e.g., Danhauer et al., 2009; Gopal, Champlin, \& Phillips, 2019). In South Korea, the incidence rate of noiseinduced hearing loss (NIHL) in 100,000 population has drastically increased by $78.2 \%$ between 2005 and 2008 with the highest incidence rate being in those in their early 20s (Jeon, Choi, \& Sakong, 2013). You, Kwak, and Han (2020) found that approximately $77.2 \%$ of 1,009 Korean college students reported being exposed to noisy environments, and that the use of PLDs was one of the most com- 
mon causes of hearing difficulties.

NIHL occurs when people are exposed to sounds at over $85 \mathrm{dBA}$ for more than 8 hours at a time and it can occur from a single loud blast for a short period of time or from gradual exposure to loud noise over time (NIDCD, 2019). When people are exposed to loud noise, they can experience a variety of hearing symptoms and hearing loss. People cannot hear or understand someone close to them, may have muffled hearing, experience soreness of ear, or ringing in their ears (i.e., tinnitus) after they hear the noise. In addition, they may experience limited concentration due to noise, have increased sensitivity to environmental sounds, and worry before attending noisy activities due to previous experience with auditory problems. Many college students reported that they had at least one hearing symptom including ear pain after noise exposure, sensitivity to noise, temporary or permanent tinnitus, worry, and selfreported hearing loss (Balanay \& Kearney, 2015; Rawool \& Colligon-Wayne, 2008; Widén et al., 2006; Widén, Holmes, Johnson, Bohlin, \& Erlandsson, 2009).

Although NIHL is irreversible and cannot be cured, it can be prevented by using hearing protection in the presence of noise. Thus, aural (re)habilitation for NIHL needs to emphasize the use of hearing protection. The Health Belief Model (Rosenstock, 1974) postulates that how individuals perceive and experience a disease can influence whether they take a recommended preventative action. Exposing oneself to noise without hearing protection can be considered a risk-taking behavior, resulting in a hearing symptom. This negative consequence can act as a catalyst for transforming the individual's risk-taking behavior into a more hearing protection using behavior (Bogoch, House, \& Kudla, 2005; Keppler, Dhooge, \& Vinck, 2015; Rawool \& Colligon-Wayne, 2008; Widén et al., 2009).

The relationships between college students' hearing symptoms, attitudes toward noise, and use of hearing protection have been investigated using self-report questionnaires, one of which is the Youth Attitudes to Noise Scale (YANS; Widén \& Erlandsson, 2004). The YANS was developed in the Swedish language (Widén \& Erlandsson, 2004) and adapted into several languages including American English, Portuguese, Chinese, Spanish, Serbian, and Korean (Widén et al., 2006; Zocoli, Morata, \& Marques, 2009; Zhu et al., 2014; Degeest, Maes, Leyssens, \& Keppler, 2018; Tomanic, Soldatovic, Jovanovic, Vukasinovic, \& Maksimovic, 2020; Han \& Kim,
2020, respectively) to evaluate youth's attitudes toward noise after their exposure to noise in noisy environments. As far as our knowledge goes, this current study is the first study to have used the Korean-version YANS.

There are two differential findings in the studies that have used the YANS (the versions in languages other than Korean) on the relationship between hearing symptoms, attitudes toward noise, and the use of hearing protection depending on college students' perception of noise produced in a given activity. On one hand, Widén and colleagues explored U.S. college students' attitudes toward noise produced in activities such as rock concerts, festivals, and sports. Results showed an association between having experience with at least one hearing symptom and a negative attitude toward noise, but the association did not trigger the use of hearing protection (Holmes, Widén, Carver, \& White, 2007; Widén et al., 2009). This is because the noise produced in those activities was considered enjoyable and acceptable and the use of hearing protection considered unnecessary. On the other hand, Balanay and Kearney (2015) investigated U.S. college students' attitudes toward noise produced in activities such as lawn mowing and the use of firearms. Results demonstrated that the association between having experience with at least one hearing symptom and a negative attitude toward noise would lead to hearing protection use because the noise produced in those activities is widely considered harmful and the use of hearing protection is taken into consideration.

These findings suggest the importance of socio-cultural contexts in evaluating college students' attitudes toward noise (Han \& Kim, 2020; Widén et al., 2009) because these contexts can influence their use of hearing protection and even hearing status. For example, Keppler et al. (2015) study with young adults in Belgium found that college students with a negative attitude toward noise had significantly less hearing loss and used hearing protection devices more frequently than those who had positive attitudes, indicating that college students who don't perceive noise as problematic tend to use hearing protection with less frequency and already have a more deteriorated hearing status. Studies with the YANS revealed that attitudes toward noise and self-reported hearing symptoms are important factors for understanding and influencing the use of hearing protection as a preventive health behavior.

However, little is known about how college students perceive 
and experience noise caused by unsafe listening practices with the PLDs they have been using for a long period of time and for long hours in a week (e.g., Marron et al., 2015), because the YANS studies (the versions in languages other than Korean) did not include question items relevant to the use of PLDs. As a result, little is known about whether college students' attitudes toward noise from PLDs can lead them to use hearing protection. In contrast, the K-YANS was developed to fully reflect the primary causes of NIHL that college students encounter in their daily lives by including question items relevant to both exposure to high levels of sound in noisy environments and unsafe listening practice for PLDs.

The purpose of the current study was to examine the relationship between Korean college students' hearing symptoms, their attitudes toward noise, and use of hearing protection. First, this current study aimed to identify what hearing symptoms college students experience in the presence of noise. Second, this study aimed to investigate whether there was a difference in attitude toward noise between those with hearing symptoms and those without hearing symptoms. In both situations: (1) when college students were exposed to high levels of sound in noisy environments; and (2) when they use their PLDs unsafely, it was hypothesized that those with hearing symptoms would perceive noise as more problematic (negative attitude toward noise) than those with no hearing symptoms based on the findings of the studies focusing on exposure to sound in noisy environments (Balanay \& Kearney, 2015; Holmes et al., 2007; Widén et al., 2006, 2009).

Third, the current study aimed to explore whether their attitudes toward noise and self-reported hearing symptoms were associated with the use of hearing protection. There was a hypothesis made for each of the following two situations: (1) when college students were exposed to high levels of sound in noisy environments; and (2) when they use their PLDs unsafely. When college students were exposed to high levels of sound in noisy environments, it was hypothesized that their negative attitude toward noise and self-reported hearing symptoms would lead to the increased use of hearing protection based on the findings of Balanay and Kearney (2015) and Widén et al. (2006). When college students use their PLDs unsafely; however, it was hypothesized that the association between college students' attitudes toward noise and their self-reported hearing symptoms would not lead to the increased use of hearing pro- tection. This is because PLDs became part of college students' necessaries and they perceived some noise as enjoyable and acceptable as seen in Holmes et al. (2007) and Widén et al. (2009). Thus, the use of hearing protection would not even be taken into consideration. The current study will provide insights into what factors may influence the change in college students' behavior from a risk-taking behavior to a more health-oriented behavior, which can help college students prevent NIHL.

\section{METHODS}

\section{Recruitment and Participants}

Inclusion criteria for the current study were Korean college undergraduates between the ages of 18 and 30 who did not have problems with speech, language, hearing, physical, and medical development. An anonymous internet survey via the Qualtrics Insight Platform system was designed for survey research. The convenient and snowball sampling methods were used for recruitment. The survey flyer with the link to the survey Qualtrics website was e-mailed to a small number of college undergraduates who were willing to participate, and to the parents and relatives of college undergraduates and to a few professors who were willing to forward the survey to students. Students who received the survey flyer were encouraged to forward the survey link to any fellow students they knew of.

A total of 516 people participated in the online survey, of whom the individuals who did not fall in the age range from 18 to 30 , were graduate students, had completed the survey multiple times, or had not completed all three sections (i.e., hearing symptom, the YANS, and hearing protection) were excluded from the study. Additionally, to verify their current enrollment at a college, those who did not respond to the question about either their college location or their grade were also excluded from the study. This exclusion process resulted in 278 college undergraduates with 62 males, 212 females, 1 other, and 3 with no responses. The average age of the 278 participants was 21.12 years $(S D=2.61)$. Table 1 presents information on the participants' age, gender, academic class standing, and college location. The participants did not receive any compensation for their participation in this survey. The current study was approved by the institutional review board. 
Table 1. Demographic information

\begin{tabular}{|c|c|c|}
\hline Demographic characteristic & $\mathrm{N}$ & $\%$ \\
\hline \multicolumn{3}{|l|}{ Age (yr) } \\
\hline $18-20$ & 139 & 50.00 \\
\hline $21-25$ & 119 & 42.81 \\
\hline $26-30$ & 20 & 7.19 \\
\hline Total & 278 & 100.00 \\
\hline \multicolumn{3}{|l|}{ Gender } \\
\hline Female & 212 & 76.26 \\
\hline Male & 62 & 22.30 \\
\hline Other & 1 & 0.36 \\
\hline No response & 3 & 1.08 \\
\hline Total & 278 & 100.00 \\
\hline \multicolumn{3}{|l|}{ Academic class standing } \\
\hline Freshman & 100 & 35.97 \\
\hline Sophomore & 55 & 19.78 \\
\hline Junior & 49 & 17.63 \\
\hline Senior & 63 & 22.66 \\
\hline No response & 11 & 3.96 \\
\hline Total & 278 & 100.00 \\
\hline \multicolumn{3}{|l|}{ College location } \\
\hline Seoul & 57 & 20.50 \\
\hline Gyeonggi-do & 32 & 11.51 \\
\hline Gangwon-do & 34 & 12.23 \\
\hline Chungcheong-do & 55 & 19.78 \\
\hline Jeolla-do & 3 & 1.08 \\
\hline Gyeongsang-do & 93 & 33.45 \\
\hline Jeju-do & 0 & 0.00 \\
\hline No response & 4 & 1.44 \\
\hline Total & 278 & 100.00 \\
\hline
\end{tabular}

\section{Survey}

The survey was designed to examine the relationship between Korean college students' experience with hearing symptoms, attitudes toward noise, and use of hearing protection. Following the informed consent, the survey has four sections with 36 questions in total (See Appendix 1 for the complete survey). The first section of the survey prompted participants to answer questions on demographic information, including the participants' gender, age, grade at school, major, city where the school is located, languages, vision, hearing, physical, and medical problems, and any experience with special education. In the second section, the survey focused on hearing symptom description including ringing/buzzing, ear fullness, hearing loss or muffled hearing, ear soreness, limited concentration due to noise, sensitivity to environmental noise, and anxiety before attending noisy activities due to previous experience with auditory problems. The third section of the survey asked the participants a question about the use of hearing protection. The last section focused on the K-YANS (Han \& Kim, 2020). The K-YANS is a valid and reliable self-report measure for assessment of NIHL in college students. Note that the K-YANS not only adapted the English-version YANS (Widén et al., 2006) including the question items relevant to the youths' exposure to high levels of sound in noisy entertainments, but also complemented them with new question items relevant to the youths' listening practices with PLDs. The K-YANS consists of 16 questions, from which five questions ask about youth culture (Factor 1), six other questions ask about concentration (Factor 2), and the remaining five questions ask about PLDs (Factor 3). The question items in Factors 1 and 2 were taken from the English-version YANS and the ones in Factor 3 were newly generated for the K-YANS.

\section{Coding and Interpretation of the K-YANS}

A 5-point Likert scale was used ranging from "strongly agree (coded as 5)" to "strongly disagree (coded as 1)" for Question items $22,25,26,28,31,34$, and 35. Inverse coding was applied to Question items $21,23,24,27,29,30,32,33$, and 36 ranging from "strongly agree (coded as 1)" to "strongly disagree (coded as 5)." For example, if a student responded to Question item 21 with "strongly agree", his or her response is coded as 1 instead of 5 .

After coding the participants' responses, the numbers obtained from all of the question items were added up together and grouped into three categories (i.e., a lower quartile, two middle quartiles, and an upper quartile) as the YANS studies have done since Widén and Erlandsson (2004) first used this same method, The criteria for each category were: a lower quartile $(\leq 29)$, two middle quartiles $(29<$ and $\leq 37)$, and an upper quartile $(37<)$ for Factors 1 and 2 (noisy environments) and lower quartile $(\leq 7)$, two middle quartiles $(7<$ and $\leq 10)$, and an upper quartile $(10<)$ for Factor 3 (use of PLDs).

Those whose scores fall within a lower quartile are identified as those with a negative attitude toward noise. They consider noise as something problematic. Those whose scores fall within two middle quartiles are identified as those with a neutral attitude toward noise, which is an indifferent attitude toward noise or uninformed of the possible consequences of noise exposure. Those whose scores 
fall within an upper quartile are identified as those with a positive attitude toward noise. They consider noise as something not problematic or dangerous. Thus, the lower the number, the more negative the youth's attitude was toward noise, suggesting that noise is perceived as something that is problematic and should be avoided; the higher the number, the more positive the youth's attitude was toward noise, suggesting that noise is perceived as acceptable, not problematic.

\section{Data Analysis}

Statistical analyses were conducted using statistical software R. First, to identify the students' self-reported hearing loss, we used descriptive statistics that analyzed the students' responses to the questions about hearing symptoms associated with noise exposure. Second, we used multinominal logistic regression in each of

Table 2. Number and percentage of self-reported hearing symptoms in college students

\begin{tabular}{lrc}
\hline Number of symptoms & N & $\%$ \\
\hline 0 & 44 & 15.83 \\
1 & 61 & 21.93 \\
2 & 104 & 37.41 \\
3 & 45 & 16.19 \\
4 & 12 & 4.32 \\
5 & 7 & 2.52 \\
6 & 5 & 1.80 \\
7 & 0 & 0 \\
Total & 278 & 100.00 \\
\hline
\end{tabular}

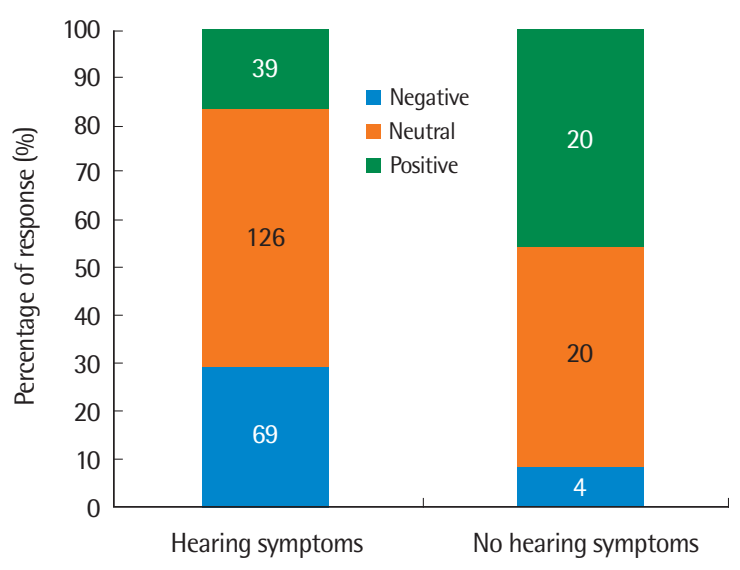

the two situations (noisy environments and use of PLDs) to investigate the association between the college students' attitudes toward noise and hearing symptom after adjusting for age effect on the attitude toward noise. Third, we used logistic regression in each of the two situations to investigate whether the participants' attitudes toward noise and their experience with hearing symptoms are associated with their use of hearing protection after adjusting for age effect on the attitude toward noise.

\section{RESULTS}

\section{Hearing Symptoms}

As seen in Table 2, only 44 students (15.83\%) reported having no hearing symptoms while 234 students (84.17\%) reported having at least one hearing symptom. Figure 1 illustrates the types of hearing

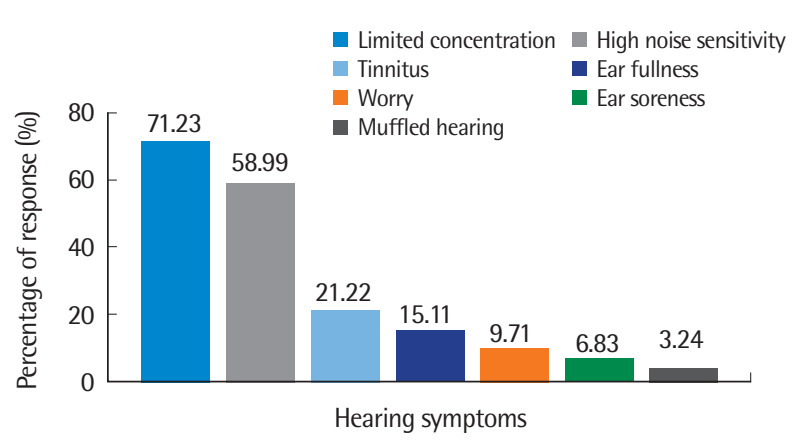

Figure 1. Types of self-reported hearing symptoms in college students.

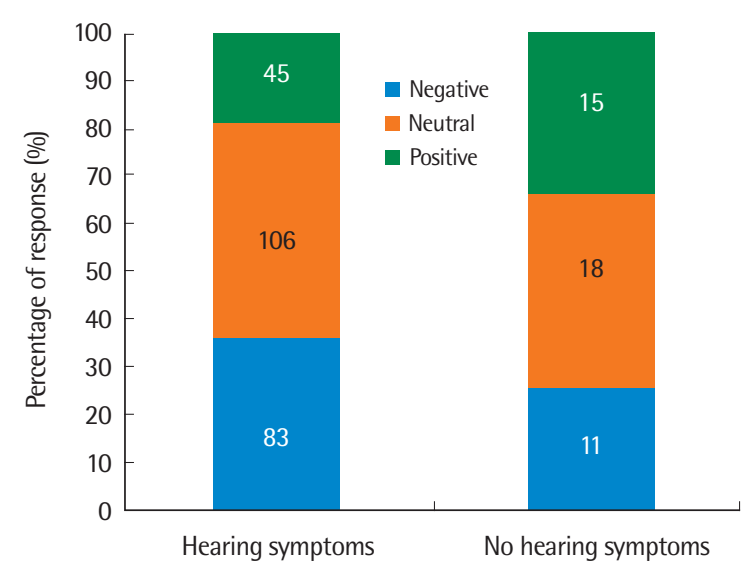

Figure 2. Number and percentage of participants in three attitudes toward noise on ${ }^{1}$ Factors 1 and 2 (left panel) and on ${ }^{2}$ Factor 3 (right panel) by hearing symptoms. ${ }^{1}$ Factors 1 and 2 represent noisy environment, ${ }^{2}$ Factor 3 represents the use of PLDs. 
symptoms reported by the 234 students, among which $71.23 \%$ of the students had experienced limited concentration and 58.99\% high noise sensitivity. In addition, tinnitus (21.22\%), ear fullness (15.11\%), worry (9.71\%), ear soreness (6.83\%), and muffled hearing (3.24\%) were reported.

\section{Hearing Symptoms and Attitudes Toward Noise}

As seen in the left panel of Figure 2, for noisy environments (Factors 1 and 2), individuals who had at least one hearing symptoms were more likely to have a negative attitude toward noise than individuals who did not have any self-reported hearing symptoms. In contrast, as seen in the right panel, for the use of PLDs (Factor 3), no great difference was seen in the percentage of individuals who had a negative attitude between those with at least one hearing symptom and those with no hearing symptoms. See Appendix 2 for the raw data of the participants' responses to the K-YANS question items.

The significant level of $\alpha=.05$ was used for all statistical analy-

Table 3. Multinomial logistic regression of hearing symptoms and attitudes toward noise on ${ }^{1}$ Factors 1 and 2

\begin{tabular}{llrrrr}
\hline & & Estimate & Std. Error & zvalue & $\operatorname{Pr}(>|z|)$ \\
\hline Negative vs. Neutral & (Intercept) & -4.88 & 1.39 & -3.52 & $<.001$ \\
attitudes & Hearing symptoms & & \\
& Age & 1.17 & .58 & 2.02 & .043 \\
\multirow{2}{*}{$\begin{array}{l}\text { Positive vs. Neutral } \\
\text { attitudes }\end{array}$} & (Intercept) & -1.71 & 1.38 & -1.24 & .216 \\
& Hearing symptoms & \\
& Age & -1.10 & .37 & -2.96 & .003 \\
& .06 & .06 & 1.27 & .203 \\
\hline
\end{tabular}

${ }^{1}$ Factors 1 and 2 represent noisy environment, ${ }^{\dagger} A$ reference for the variable hearing symptoms is no hearing symptoms. A reference for the dependent variable is neutral attitude.

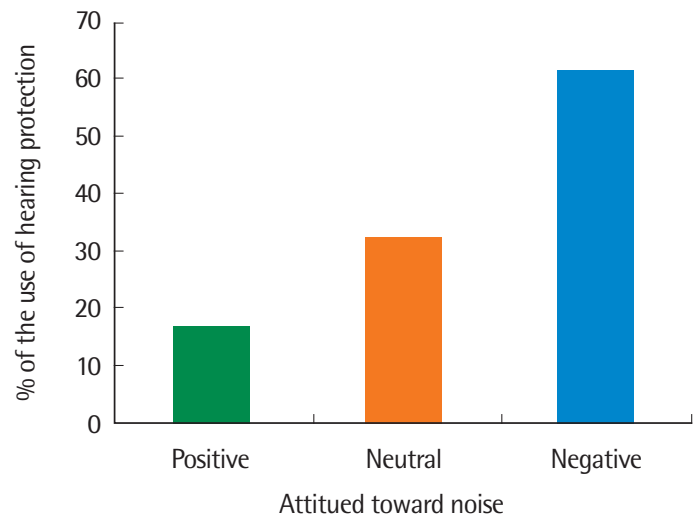

ses. Table 3 presents the results of the multinominal logistic regression of hearing symptoms and attitudes toward noise in noisy environments (Factors 1 and 2). Experience with a hearing symptom has a significant effect on the college students' attitude toward noise in noisy environments. Those who experienced a hearing symptom tend to have a negative attitude over a neutral attitude $(z=2.02$, $p=.043)$; and a neutral attitude over a positive attitude $(z=-2.96$, $p=.003)$ compared to those with no hearing symptoms. Results suggest that college students with at least one hearing symptom consider noise to be more problematic (i.e., something they would want to avoid) in noisy environments than those with no hearing symptoms. Additionally, there was an age effect on the students' attitudes toward noise in noisy environment. The students tend to have a more negative attitude with age $(z=2.61, p=.009)$.

Table 4 presents the results of the multinominal logistic regression of hearing symptoms and attitudes toward noise when using PLDs (Factor 3). Experience with a hearing symptom has no significant effect on whether the college students' attitude toward

Table 4. Multinomial logistic regression of hearing symptoms and attitudes toward noise on ${ }^{2}$ Factor 3

\begin{tabular}{llcrrr}
\hline & & Estimate & Std. Error & zvalue & $\operatorname{Pr}(>|z|)$ \\
\hline Negative vs. Neutral (Intercept) & 1.62 & 1.28 & 1.27 & .205 \\
attitudes & Hearing symptoms ${ }^{\dagger}$ & .17 & .42 & .41 & .685 \\
& Age & -.10 & .06 & -1.73 & .084 \\
\multirow{2}{*}{$\begin{array}{l}\text { Positive vs. Neutral } \\
\text { attitudes }\end{array}$} & (Intercept) & .00 & 1.35 & .01 & .995 \\
& Hearing symptoms & \\
& Age & -.68 & .40 & -1.72 & .085 \\
& -.01 & .06 & -.15 & .883 \\
\hline
\end{tabular}

${ }^{2}$ Factor 3 represents the use of PLDs, ${ }^{\dagger} A$ reference for the variable hearing symptoms is no hearing symptoms. A reference for the dependent variable is neutral attitude.

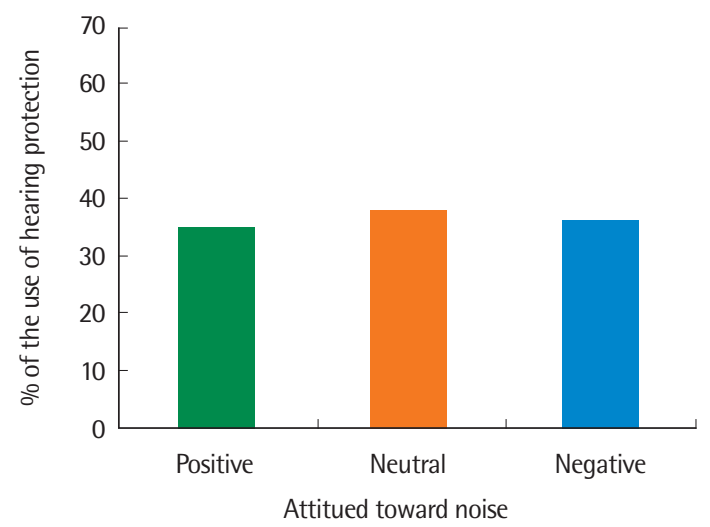

Figure 3. Proportion of participants who used hearing protection by experience with hearing symptoms for ${ }^{1}$ Factors 1 and 2 (left panel) and ${ }^{2}$ Factor 3 (right panel). ${ }^{1}$ Factors 1 and 2 represent noisy environment, ${ }^{2}$ Factor 3 represents the use of PLDs. 
Table 5. Logistic regression of hearing symptoms, attitudes toward noise on ${ }^{1}$ Factors 1 and 2 , and use of hearing protection

\begin{tabular}{lcccc}
\hline & Estimate & Std. Error & $z$ value & $\operatorname{Pr}(>|z|)$ \\
\hline (Intercept) $_{\text {Hearing symptoms }}^{\dagger}$ & -1.24 & 1.32 & -.94 & .349 \\
Neutral attitude to noise $^{\ddagger}$ & 1.40 & .51 & 2.71 & .007 \\
Positive attitude to noise $^{\ddagger}$ & -1.14 & .31 & -3.71 & $<.001$ \\
Age & -1.80 & .43 & -4.15 & $<.001$ \\
\hline
\end{tabular}

${ }^{1}$ Factors 1 and 2 represent noisy environment, ${ }^{\dagger} A$ reference for the variable hearing symptoms is no hearing symptoms, ${ }^{\ddagger} A$ reference for the variables attitudes toward noise is negative.

noise is negative $(z=.41, p=.685)$ or positive $(z=-1.72, p=.085)$ when using PLDs. In addition, there was no significant age effect on attitudes toward noise when using PLDs. Results suggest that college students do not tend to consider noise from their PLD to be either problematic or acceptable.

\section{Hearing Symptoms, Attitudes Toward Noise, and Use of Hearing Protection}

As seen in Figure 3, among the college students with at least one hearing symptom, those who have a negative attitude toward noise use hearing protection in noisy environments more than those who have a neutral or positive attitude. However, the percentages of hearing protection use were similar across all three attitudes toward noise when using PLDs.

Table 5 presents the results of the logistic regression when the college students were exposed to high levels of sound in noisy environments (Factors 1 and 2). There was a significant effect of hearing symptoms on the use of hearing protection $(z=2.71, p=.007)$, indicating that those with at least one hearing symptom in noisy environments are more likely to use hearing protection than those with no hearing symptoms. Moreover, those with a neutral $(z=$ $-3.71, p<.001)$ or a positive $(z=-4.15, p<.001)$ attitude toward noise used a form of hearing protection less than those with a negative attitude toward noise. In addition, there was no significant age effect $(z=.35, p=.729)$ on the use of hearing protection. Results suggest that college students who have a hearing symptom or a negative attitude tend to use hearing protection in noisy environments more often than those who do not have a hearing symptom or have a positive or neutral attitude.

Table 6 presents the results of the logistic regression for the use
Table 6. Logistic regression of hearing symptoms, attitudes toward noise on ${ }^{2}$ Factor 3 , and use of hearing protection

\begin{tabular}{lcccc}
\hline & Estimate & Std. Error & zvalue & $\operatorname{Pr}(>|z|)$ \\
\hline Intercept) & -3.00 & 1.21 & -2.47 & .013 \\
Hearing Symptoms $^{\dagger}$ & 1.76 & .50 & 3.53 & $<.001$ \\
Neutral attitude to noise $^{\ddagger}$ & .09 & .29 & .30 & .763 \\
Positive attitude to noise $^{\ddagger}$ & .11 & .36 & .30 & .767 \\
Age & .04 & .05 & .78 & .433 \\
\hline
\end{tabular}

${ }^{2}$ Factor 3 represents the use of PLDs, ${ }^{\dagger} A$ reference for the variable hearing symptoms is no hearing symptoms, ${ }^{\ddagger} A$ reference for the variables attitudes toward noise is negative.

of PLDs (Factor 3) that showed a significant association between hearing symptoms and the use of hearing protection $(z=3.53, p<$ .001 ), indicating that those with at least one hearing symptom are more likely to use hearing protection than those with no hearing symptoms. However, there were no differences between hearing protection use and the attitudes toward noise when using PLDs $(z=.30, p=.763$ for neutral attitude; $z=.30, p=.767$ for positive attitude). Additionally, there was no significant age effect $(z=.78$, $p=.433$ ) on the use of hearing protection. Results suggest that when using PLDs, their experience with a hearing symptom tends to trigger their use of hearing protection but their attitudes toward noise do not.

\section{DISCUSSION \& CONCLUSION}

The main purpose of this study was to investigate the relationship between college students' hearing symptoms, attitudes toward noise, and use of hearing protection both when they were exposed to high levels of sound in noisy environment and when using their PLDs. This study was designed, in particular, to identify college students' self-reported hearing symptoms caused by exposure to noise, explore the association between college students' attitudes toward noise and their self-reported hearing symptoms, and examine whether their experience with hearing symptoms and attitudes toward noise are associated with the use of hearing protection. Over $84 \%$ of the college students reported having at least one hearing symptom caused by noise; with limited concentration rated most frequently, followed by high noise sensitivity, tinnitus, ear fullness, worry, ear soreness, and muffled hearing rated least frequently. When the college students were exposed to high levels of 
sound in noisy environments, those with at least one hearing symptom had a negative attitude toward noise more than those with no hearing symptoms. When they used their PLDs, however, there was no significant association between their attitudes toward noise and hearing symptoms. When the college students were exposed to high levels of sound in noisy environments, those with at least one hearing symptom or a negative attitude toward noise used hearing protection more often than their counterparts. When using PLDs, those with hearing symptoms used hearing protection more often than those with no hearing symptoms, but there was no significant association between their attitudes toward noise and their use of hearing protection.

$84.17 \%$ of Korean college students reported their experience with at least one hearing symptom. Among the studies with the YANS and its relationship with hearing symptoms, this is a surprisingly high number compared to $39.6 \%$ of U.S. college students in Balanay and Kearney (2015). The most frequently reported hearing symptom in this study was limited concentration, as opposed toear pain after noise exposure in Balanay and Kearney (2015). Many studies on NIHL revealed tinnitus as being the most frequently reported hearing symptom in teenagers and young adults who are using PLDs and involved in various activities (Bogoch et al., 2005; Chung, Des Roches, Meunier, \& Eavey, 2005; Degeest, Corthals, Vinck, \& Keppler, 2014; Olsen-Widen \& Erlandsson, 2004). Korean college students seem to suffer more from psycho-social effects of noise such as concentration and noise sensitivity than from medical factors such ear pain and tinnitus. These results indicate that an individual's perception and experience with hearing symptoms may vary depending on their social, cultural, and environmental background.

Regarding the association between college students' self-reported hearing symptoms and attitudes toward noise, it was hypothesized that those with hearing symptoms would perceive noise to be more negative than those with no hearing symptoms in both situations, when they were exposed to high levels of sound in noisy environment and when they were using PLDs. when the college students were exposed to high levels of sound in noisy environments, the results verified the hypothesis. The college students who self-reported having at least one hearing symptom are more likely to perceive noise as something negative and problematic to their health (i.e., something to be avoided) compared to those who self-reported having no hearing symptoms. This is consistent with the results in past studies (Balanay \& Kearney, 2015; Holmes et al., 2007; Widén et al., 2009). The results imply that those with hearing symptoms caused by exposure to noise in their environment may have an increased awareness of noise and its deleterious effects on their hearing, which may serve to develop their negative attitudes toward noise. Additionally, this study found a significant age effect, with a greater likelihood of having a negative attitude toward noise with age. Older students may have been exposed to noise longer and have more chances to experience the negative effects of noise than younger students, causing older students to have a more negative attitude toward noise.

When college students used their PLDs, however, the results found no significant association between their attitudes toward noise and hearing symptoms, which did not verify our hypothesis. This result was consistent with the finding of You et al. (2020)'s survey research on the use of PLDs in Korean college students who did not accept any possible association between their PLD use and experience with hearing symptoms. A possible explanation for this lack of association is that since PLDs have become a necessity among college students and they use their PLDs in their everyday environments, they may not take into consideration the unsafe use of their PLDs to be a risk-taking behavior. As a result, college students may not have any negative or positive attitudes toward noise regardless of their experience with hearing symptoms, resulting in there being insignificant association between hearing symptoms and attitudes toward noise.

Regarding the use of hearing protection, when the college students were exposed to high levels of sound in noisy environments, the results verified our hypothesis that those with at least one hearing symptom or a negative attitude toward noise would use more hearing protection than their counterparts. The results showed that the use of hearing protection was associated with both hearing symptoms and attitudes toward noise. This is consistent with the findings in Balanay and Kearney (2015) which revealed that those with at least one hearing symptom tend to have a negative attitude toward noise, and that these outcomes are associated with the use of hearing protection. These results support the Health Belief Model that can be applied to college students' risk-taking behavior (i.e., 
exposure to noise in their environments), which may produce negative outcomes (i.e., a hearing symptom and a negative attitude toward noise). These negative outcomes may serve as a trigger to a health-oriented behavior (i.e., use of hearing protection).

However, the Health Belief Model may not be applied to college students' PLD use. The results did not verify our hypothesis that there would be an association between the attitudes and hearing symptoms, and the association would not lead to the increased use of hearing protection. The results revealed, first, that there was no association between the attitudes and hearing symptoms and, secondly, that the use of hearing protection was associated with hearing symptoms, but not with attitudes toward noise. Not surprisingly, the use of hearing protection was associated with hearing symptoms because those with hearing symptoms may be more aware of the negative effects of noise on hearing and more likely to use hearing protection than those with no hearing symptoms. As discussed above, college students may not consider the unsafe use of their PLDs to be a risk-taking behavior, which may not produce any attitude toward noise, resulting in there being no significant association between the use of hearing protection and attitudes toward noise.

The K-YANS was developed to reflect the two causes of NIHL in college students as indicated by the WHO (2015) exposure to high levels of sound in noisy environments and unsafe listening practices with PLDs. College students may consider their exposure to high levels of sound in noisy environments to be a risk-taking behavior, producing a negative attitude noise that can serve as a trigger to a health-oriented behavior (i.e., use of hearing protection). In contrast, college students may not consider their unsafe listening practices with PLDs to be a risk-taking behavior regardless of the presence of self-reported hearing symptoms, producing neither negative nor positive attitudes toward noise. As a result, there may be a higher risk for unpreventable NIHL when colleges students use their PLDs unsafely than when they are exposed to high levels of sound in noisy environments. Along with these findings on the use of PLDs in college students, the results of You et al. (2020) provide a window into aural (re)habilitation for NIHL in Korean college students. You et al. (2020) revealed that Korean college students are knowledgeable about the signs of NIHL, the negative effects of PLD use, and the fact that NIHL is preventable. In contrast, they are not knowledgeable about safe listening practices with PLDs and demonstrate little desire to change their PLD use pattern (e.g., lengths of PLD use, volume setting on PLD, and listening environments). Thus, hearing conservative programs should place greater focus on educating college students on how to use PLDs safely and transforming their attitudes toward noise, which can encourage them to take preventative measures against severe and permanent noise-induced hearing loss.

It is important to note that there were some limitations to the current study. The responses to a self-reporting survey are inherently biased due to the participants' personal experiences being relatively subjective. This might be especially true of our participants' report of their hearing symptoms associated with noise. They might have overreported or underreported their hearing symptoms. It is also possible that the participants' response to the question regarding whether they have normal hearing in the demographic information section might be inconsistent with their response to the question regarding whether they have a hearing loss or muffled hearing in the hearing symptom description section. More accurate data can be obtained when the self-reported information is combined with other medical reports on their hearing status. In addition, the study's sample did not include an equal amount of female and male participants and did not represent all the regions of South Korea, which may limit the generalizability of the study results. Future research may consider adopting a stratified sampling strategy which is used to generate a sample that represents the population of interest.

\section{REFERENCES}

Balanay, J. A. G., \& Kearney, G. D. (2015). Attitudes toward noise, perceived hearing symptoms, and reported use of hearing protection among college students: influence of youth culture. Noise \& Health, 17(79), 394-405.

Berger, E. H., Neitzel, R., \& Kladden, C. A. (2015). Noise Navigator ${ }^{\mathrm{TM}}$ sound $^{-}$ level database with vver 1700 measurement values. Retrieved from www.ea-r.com/pdf/hearingcons/NoiseNavigatorDatabase.xls.

Bogoch, I. I., House, R. A., \& Kudla, I. (2005). Perceptions about hearing protection and noise-induced hearing loss of attendees of rock concerts. $\mathrm{Ca}$ nadian Journal of Public Health, 96(1), 69-72.

Chung, J. H., Des Roches, C. M., Meunier, J. E., \& Eavey, R. D. (2005). Evalu- 
ation of noise-induced hearing loss in young people using a web-based survey technique. Pediatrics, 115(4), 861-867.

Danhauer, J. L., Johnson, C. E., Byrd, A., DeGood, L., Meuel, C., Pecile, A., \& Koch, L. L. (2009). Survey of college students on iPod use and hearing health. Journal of the American Academy of Audiology, 20(1), 5-27.

Degeest, S., Corthals, P., Vinck, B., \& Keppler, H. (2014). Prevalence and characteristics of tinnitus after leisure noise exposure in young adults. Noise \& Health, 16(68), 26-33.

Degeest, S., Maes, L., Leyssens, L., \& Keppler, H. (2018). The test-retest reliability of questionnaires regarding attitudes and beliefs toward noise, hearing loss, and hearing protector devices in young adults. Noise \& Health, 20(93), 31-36.

Gopal, K. V., Champlin, S., \& Phillips, B. (2019). Assessment of safe listening intentional behavior toward personal listening devices in young adults. International Journal of Environmental Research and Public Health, 16(17), $1-11$.

Han, M., \& Kim, S. (2020). A Study on the Korean-Version of Youth Attitudes to Noise Scale (K-YANS). Communication Sciences \& Disorders, 5(3), 764773.

Holmes, A. E., Widén, S. E., Carver, C. L., \& White, L. L. (2007). Perceived hearing status and attitudes toward noise in young adults. American Journal of Audiology, 16(2), S182-S189.

Jeon, M. E., Choi, E. J., \& Sakong, J. (2013). Incidence rate of noise induced hearing loss in Korean youths using national health insurance data. The Journal of Korean Society for School \& Community Health Education, 14(2), 93-112.

Keppler, H., Dhooge, I., \& Vinck, B. (2015). Hearing in young adults. Part I: the effects of attitudes and beliefs toward noise, hearing loss, and hearing protector devices. Noise \& Hearing, 17(78), 237-244.

Kreisman, B. M., Longenbach, K. M., Blasi, M. A., Fligor, B. J., \& John, A. B. (2019). The effects of background noise and personal MP3 player volume on the audibility to bystanders. Journal of Educational, Pediatric \& $(\mathrm{Re}) \mathrm{Ha}$ bilitative Audiology, 24, 1-13.

Marron, K. H., Marchiondo, K., Stephenson, S., Wagner, S., Cramer, I., Wharton, T., Hughes, M., Sproat, B., \& Alessio, H. (2015). College students' personal listening device usage and knowledge. International Journal of Audi- ology, 54(6), 384-390.

National Institute on Deafness and Other Communicate Disorders. (2019). Noise-induced hearing loss. Retrieved from https://www.nidcd.nih.gov/ health/noise-induced-hearing-loss.

Olsen-Widen, S. E., \& Erlandsson, S. I. (2004). Self-reported tinnitus and noise sensitivity among adolescents in Sweden. Noise \& Health, 7(25), 2940.

Rawool, V. W., \& Colligon-Wayne, L. A. (2008). Auditory lifestyles and beliefs related to hearing loss among college students in the USA. Noise \& Health, 10(38), 1-10.

Rosenstock, I. M. (1974). The Health Belief Model and preventive health, behavior. Health Education Monographs, 2(4), 354-386.

Tomanic, M., Soldatovic, I., Jovanovic, A., Vukasinovic, D., \& Maksimovic, M. (2020). Translation, adaptation and validation of the youth attitude to noise scale (YANS) questionnaire into Serbian language. Noise \& Health, 22(105), 56-61.

You, S., Kwak, C., \& Han, W. (2020). Use of personal listening devices and knowledge/attitude for greater hearing conservation in college students: data analysis and regression model based on 1009 respondents. International Journal of Environmental Research and Public Health, 17(8), 1-23.

Widén, S. E., \& Erlandsson, S. I. (2004). Self-reported tinnitus and noise sensitivity among adolescents in Sweden. Noise \& Health, 7(25), 29-40.

Widén, S. E., Holmes, A. E., \& Erlandsson, S. I. (2006). Reported hearing protection use in young adults from Sweden and the USA: effects of attitude and gender. International Journal of Audiology, 45(5), 273-280.

Widén, S. E., Holmes, A. E., Johnson, T., Bohlin, M., \& Erlandsson, S. I. (2009). Hearing, use of hearing protection and attitudes towards noise among young American adults. International Journal of Audiology, 48(8), 537-545.

World Health Organization. (2015). World hearing day 2015: make listening safe. Retrieved from https://www.who.int/pbd/deafness/activities/MLS/en/.

Zocoli, A. M., Morata, T. C., \& Marques, J. M. (2009). Youth attitude to noise scale (YANS) questionnaire adaptation into Brazilian Portuguese. Brazilian Journal of Otorhinolaryngology, 75(4), 485-492.

Zhu, X., Bihi, A., Hu, X., Lv, Y., Abbas, A., Zhu, X., Mo, L., \& Peng, X. (2014). Chinese-adapted youth attitude to noise scale: evaluation of validity and reliability. Noise \& Health, 16(71), 218-222. 
Appendix 1. Online Survey

Section 1. Demographic Information

1. 성별을 선택해 주세요.

남자

여자

기타

2. 연령(만 나이)을 기입해 주세요.

3. 몇 학년인가요?

4. 전공을 기입해 주세요.

5. 현재 재학 중인 학교가 위치한 도시명을 기입해 주세요

6. 본 연구에 처음 참여하시나요?

예

“아니오”라면 몇 번째 참여하시는 건가요?

7. 이 설문조사를 어떻게 알게 되었나요?

8. 한국어 외에 다른 나라 언어를 구사하실 수 있나요?

"예"라면 어떤 외국어를 구사하실 수 있나요?

아니오

9. 정상 시력을 가지고 계십니까(안경을 꼈을 때나 안경을 안겼을 때)?

예

“아니오”라면 시력문제를 기술하여 주세요.

10. 정상 청력을 가지고 계십니까?

예

"아니오”라면 청력문제를 기술하여 주세요

11. 본 연구 참여에 영향을 미칠 만한 신체적, 의학적 문제가 있으신가요? "예"라면 그 문제를 기술해 주세요

아니오

12. 특수교육 혹은 재활 서비스를 받으신 경험이 있습니까?

"예"라면 그 서비스를 왜 받으셨고 얼마나 오래 받으셨나요?

아니오

\section{Section 2. Hearing Symptom Description}

13. 귀울림 (이명)이 있으신가요?

어떤 활동을 했을 때 이명이 처음 생겼나요?

14. 귀가 꽉 막힌 것 같은 먹먹한 증상(이충만감)이 있으신가요?

어떤 활동을 했을 때 이 증상이 처음 생겼나요? 
15. 청력 상실 또는 청력 저하가 있으신가요?

어떤 활동을 하셨을 때 처음으로 이 증상이 발생했나요?

16. 귀통증(이통)이 있으신가요?

어떤 활동을 하셨을 때 처음으로 이 증상이 발생했나요?

17. 소음 때문에 집중력이 감소되는 경험을 하셨나요?

18. 당신은 주변 소음에 민감한 편이라고 생각하시나요?

19. 청력 문제를 경험한 적이 있어서, 소음이 심한 활동에 참석하는 것이 걱정스러우신가요?

\section{Section 3. The Use of Hearing Protection}

20. 나는 소음이 심한 곳에서는 꼭 청력보호장비를 착용한다.

예

아니오

\section{Section 4. Korean version of the Youth Attitudes to Noise Scale*}

21. 나는 일반적으로 클럽, 콘서트, 축제, 스포츠 행사에서 발생하는 소리가 지나치게 크다고 생각한다.
매우 그렇다
그렇다
보통이다
그렇지 않다
전혀 그렇지 않다

22. 내가 다니는 학교 안의 소음은 적당한 편이다.
매우 그렇다
그렇다
보통이다
그렇지 않다
전혀 그렇지 않다

23. 클럽, 콘서트, 축제, 스포츠 행사에서 발생하는 소리가 너무 크면, 나는 그 장소를 나올 수도 있다.
매우 그렇다
그렇다
보통이다
그렇지 않다
전혀 그렇지 않다

24. 운전을 하거나 자전거를 탈 때 이어폰이나 헤드폰을 착용하는 것은 위험하다고 생각한다.

$\begin{array}{llll}\text { 매우 그렇다 그렇다 } & \text { 보통이다 } & \text { 그렇지 않다 }\end{array}$

25. 주위에서 여러 소리가 들리더라도 나는 집중할 수 있다.
매우 그렇다
그렇다
보통이다
그렇지 않다
전혀 그렇지 않다

26. 내가 클럽, 콘서트, 축제, 스포츠 행사에 갔을 때, 귀마개를 사용할 필요가 없다고 생각한다.
매우 그렇다
그렇다
보통이다
그렇지 않다
전혀 그렇지 않다

27. 소음이 심한 곳에서 음악 감상 등을 위해 이어폰이나 헤드폰을 오래 사용하면 청력이 손상될 수 있다고 나는 생각한다.
매우 그렇다
그렇다
보통이다
그렇지 않다
전혀 그렇지 않다

28. 클럽, 콘서트, 축제, 스포츠 행사에서 발생하는 소리를 시끄러운 소음으로 생각하지 않는다
매우 그렇다
그렇다
보통이다
그렇지 않다
전혀 그렇지 않다

29. 이어폰이나 헤드폰 착용한 채 대화를 하면, 정상적인 의사소통에 방해가 될 수 있다고 나는 생각한다.

매우 그렇다 그렇다 $\quad$ 보통이다 그렇지 않다

30. 소음과 큰 소리는 우리 사회에서 흔하게 경험하는 것이다.

매우 그렇다 그렇다 보통이다 그렇지 않다 전혀 그렇지 않다

31. 자동차의 소음이 내 일이나 공부를 방해하지 않는다.

매우 그렇다 그렇다 보통이다 그렇지 않다 전혀 그렇지 않다 
32. 클럽, 콘서트, 축제, 스포츠 행사에서 발생하는 소리의 크기를 줄여야 한다.
매우 그렇다
그렇다
보통이다
그렇지 않다
전혀 그렇지 않다

33. 신경 쓰이는 소리를 없애지 못했을 때, 나는 무력감을 느낀다.

매우 그렇다 그렇다 보통이다

34. 환풍기, 냉장고, 컴퓨터 등에서 나는 소리가 내 일이나 공부를 방해하지 않는다.

매우 그렇다

그렇다

보통이다

그렇지 않다

전혀 그렇지 않다

35. 나는 자동차나 도로에서 들리는 소리에 민감하지 않다.
매우 그렇다
그렇다
보통이다
그렇지 않다
전혀 그렇지 않다

36. 이어폰이나 헤드폰을 착용한 상태로 길을 걸으면, 신호등이나 차량의 이동 소리를 못 들을 수 있다고 나는 생각한다.
매우 그렇다
그렇다
보통이다
그렇지 않다
전혀 그렇지 않다

* Inverse coding was applied to Question items 21, 23, 24, 27, 29, 30, 32, 33, and 36 in italic. 
Appendix 2. Raw data for the participants' responses to the K-YANS

\begin{tabular}{|c|c|c|c|c|c|}
\hline \multirow{2}{*}{ Question item } & \multicolumn{5}{|c|}{ Number of participants' responses (\%) } \\
\hline & 매우 그렇다 & 그렇다 & 보통이다 & 그렇지 않다 & 전혀 그렇지 않다 \\
\hline $\begin{array}{l}\text { Q21. 나는 일반적으로 클럽, 콘서트, 축제, 스포츠 행사에서 발생 } \\
\text { 하는 소리가 지나치게 크다고 생각한다. }\end{array}$ & $7(2.52 \%)$ & $32(11.51 \%)$ & $60(21.58 \%)$ & $126(45.32 \%)$ & $53(19.06 \%)$ \\
\hline Q22. 내가 다니는 학교 안의 소음은 적당한 편이다. & $23(8.27 \%)$ & $170(61.15 \%)$ & $74(26.62 \%)$ & $10(3.60 \%)$ & $1(0.36 \%)$ \\
\hline $\begin{array}{l}\text { Q23. 클럽, 콘서트, 축제, 스포츠 행사에서 발생하는 소리가 너무 } \\
\text { 크면, 나는 그 장소를 나올 수도 있다. }\end{array}$ & $9(3.24 \%)$ & $43(15.47 \%)$ & $46(16.55 \%)$ & $120(43.17 \%)$ & $60(21.58 \%)$ \\
\hline $\begin{array}{l}\text { Q24. 운전을 하거나 자전거를 탈 때 이어폰이나 헤드폰을 } \\
\text { 착용하는 것은 위험하다고 생각한다. }\end{array}$ & $4(1.44 \%)$ & $17(6.12 \%)$ & $30(10.79 \%)$ & $104(37.41 \%)$ & $123(44.24 \%)$ \\
\hline Q25. 주위에서 여러 소리가 들리더라도 나는 집중할 수 있다. & $14(5.04 \%)$ & $61(21.94 \%)$ & $101(36.33 \%)$ & $93(33.45 \%)$ & $9(3.24 \%)$ \\
\hline $\begin{array}{l}\text { Q26. 내가 클럽, 콘서트, 축제, 스포츠 행사에 갔을 때, 귀마개를 } \\
\text { 사용할 필요가 없다고 생각한다. }\end{array}$ & $28(10.07 \%)$ & $150(53.96 \%)$ & $64(23.02 \%)$ & $28(10.07 \%)$ & $8(2.88 \%)$ \\
\hline $\begin{array}{l}\text { Q27. 소음이 심한 곳에서 음악 감상 등을 위해 이어폰이나 헤드폰을 } \\
\text { 오래 사용하면 청력이 손상될 수 있다고 나는 생각한다. }\end{array}$ & $3(1.08 \%)$ & $11(3.96 \%)$ & $18(6.47 \%)$ & $125(44.96 \%)$ & $121(43.53 \%)$ \\
\hline $\begin{array}{l}\text { Q28. 클럽, 콘서트, 축제, 스포츠 행사에서 발생하는 소리를 시끄 } \\
\text { 러운 소음으로 생각하지 않는다. }\end{array}$ & & $11(3.96 \%)$ & $55(19.78 \%)$ & $73(26.26 \%)$ & $112(40.29 \%)$ \\
\hline $\begin{array}{l}\text { Q29. 이어폰이나 헤드폰 착용한 채 대화를 하면, 정상적인 의사 } \\
\text { 소통에 방해가 될 수 있다고 나는 생각한다. }\end{array}$ & $2(0.72 \%)$ & $5(1.80 \%)$ & $14(5.04 \%)$ & $111(39.93 \%)$ & $146(52.52 \%)$ \\
\hline Q30. 소음과 큰 소리는 우리 사회에서 흔하게 경험하는 것이다. & $74(26.62 \%)$ & $162(58.27 \%)$ & $36(12.95 \%)$ & $6(2.16 \%)$ & $0(0 \%)$ \\
\hline Q31. 자동차의 소음이 내 일이나 공부를 방해하지 않는다. & $17(6.12 \%)$ & $71(25.54 \%)$ & $84(30.22 \%)$ & $90(32.37 \%)$ & $16(5.76 \%)$ \\
\hline $\begin{array}{l}\text { Q32. 클럽, 콘서트, 축제, 스포츠 행사에서 발생하는 소리의 크기를 } \\
\text { 줄여야 한다. }\end{array}$ & $3(1.08 \%)$ & $62(22.30 \%)$ & $108(38.85 \%)$ & $77(27.7 \%)$ & $28(10.07 \%)$ \\
\hline Q33. 신경 쓰이는 소리를 없애지 못했을 때, 나는 무력감을 느낀다. & $33(11.87 \%)$ & $104(37.41 \%)$ & $70(25.18 \%)$ & $58(20.86 \%)$ & $13(4.68 \%)$ \\
\hline $\begin{array}{l}\text { Q34. 환풍기, 냉장고, 컴퓨터 등에서 나는 소리가 내 일이나 공부를 } \\
\text { 방해하지 않는다. }\end{array}$ & $64(23.02 \%)$ & $117(42.09 \%)$ & $45(16.19 \%)$ & $42(15.11 \%)$ & $10(3.60 \%)$ \\
\hline Q35. 나는 자동차나 도로에서 들리는 소리에 민감하지 않다. & $23(8.27 \%)$ & $87(31.29 \%)$ & $102(36.69 \%)$ & $60(21.58 \%)$ & $6(2.16 \%)$ \\
\hline $\begin{array}{l}\text { Q36. 이어폰이나 헤드폰을 착용한 상태로 길을 걸으면, 신호등이나 } \\
\text { 차량의 이동 소리를 못 들을 수 있다고 나는 생각한다. }\end{array}$ & $3(1.08 \%)$ & $4(1.44 \%)$ & $25(8.99 \%)$ & $128(46.04 \%)$ & $118(42.45 \%)$ \\
\hline
\end{tabular}




\section{국문초록}

\section{대학생들의 청각이상증상, 소음에 대한 태도 및 청력보호장비 사용 간의 관계}

한민경 $\cdot$ 김선진

1인디애나주립대학교 언어치료학과, ${ }^{2}$ 마이애미대학교 통계학과

배경 및 목적: 청(소)년들은 여가나 오락 등 소음이 발생하는 활동에 많이 참여하고 개인용 음향장치를 안전하지 않게 사용하면서 심 각한 소음에 노출되어 있다. 이에 본 연구는 대학생들의 청각이상증상과 소음에 대한 태도, 청력보호장비 사용 간의 관계를 알아보고 자 하였다. 방법: 대학생 278 명이 온라인 설문조사에 무기명으로 참여하여, 청각이상증상, 소음에 대한 태도, 청력보호장비 사용에 대 한 질문에 응답하였다. 결과: 본 연구에 참여한 대학생 $84 \%$ 이상이 소음으로 인한 청각이상증상을 적어도 하나 이상을 경험한다고 보 고 하였는데 이 중, 소음으로 인한 집중력 저하를 경험하는 학생들이 가장 많았다. 소음환경에서, 청각이상증상을 경험하는 학생일수 록 그렇지 않은 학생에 비해 소음을 문제로 인식하였고, 소음으로 생긴 청각이상증상을 경험할수록, 그리고 소음에 대해 부정적인 태 도를 갖을수록 그렇지 않은 학생들보다 청력보호장비를 더 자주 사용하였다. 그러나 개인용 음향장치를 사용할 때는, 청각이상증상과 소음에 대한 태도 간에는 유의미한 연관성이 없고, 소음으로 생긴 청각이상증상을 경험할수록 청력보호장비를 더 자주 사용하였으나 부정적인 태도와 청력보호장비 사용 간에는 유의미한 연관성이 없었다. 논의 및 결론: 대학생들이 소음을 어떻게 경험하고 인식하느 냐가 소음성 청각장애 예방 조치를 취하는 데 영향을 미칠 수 있다. 따라서 소음성 청각장애 예방 프로그램을 통해, 대학생들이 소음의 위험성을 인지하고 소음에 대한 태도를 바꾸어 소음성 청각장애 예방 조치를 취하도록 도와주어야 할 것이다.

핵심어: 소음성 청각장애, 청각이상증상, 소음에 대한 태도, 청력보호장비

본 연구는 미국 인디애나 라이온즈클럽 언어청각프로젝트: 맥키니 연구기금 지원을 받아수행되었음.

\section{참고문헌}

전만중, 최은주, 사공준 (2013). 건강보험 자료에 의한 우리나라 청소년의 소음성 난청 환자 발생 양상. 한국학교보건교육학회지, 14(2), 93-112. 한민경, 김선진 (2020). 한국어용 소음에 대한 청(소)년의 태도측정 검사도구(K-YANS) 개발 연구. Communication Sciences \& Disorders, 25(3), 764-773.

\section{ORCID}

한민경(제1저자, 교신저자, 교수 https://orcid.org/0000-0002-9501-8187); 김선진(공동저자, 교수 https://orcid.org/0000-0001-6058-0420) 